\title{
$\left[{ }^{18} \mathrm{~F}\right]$ FDG-PET の健康保険適用外悪性腫瘍への 適用拡大による医療経済的影響
}

\author{
本田憲業，伊藤健吾*，鳥塚莞爾** \\ 埼玉医科大学総合医療センター放射線科 \\ 350-8550 埼玉県川越市鴨田辻道 1981 \\ *国立長寿医療センター \\ 474-8522 愛知県大府市森岡町源吾 36-3 \\ **財団法人 体質研究会 \\ 606-8225 京都府京都市左京区田中門前町 103-5 パストゥールビル 5F \\ 2007 年 9 月 10 日 受理

\begin{abstract}
我が国の健康保険において， $\left.{ }^{18} \mathrm{~F}\right] \mathrm{FDG}-\mathrm{PET}$ 及び PET/CT（以下 PET/CT 等）をすべての悪性 腫瘍に適用を拡大した場合の医療費への影響を試算した。2004〜 2006 年の 3 回の全国 PET 施設 アンケート調查から，2008 年の年間検查件数は 275785 件と推定した。同アンケート調查にて得ら れた，検查料の $20 \%$ が削減された検查件数の割合と, PET と PET/CT の検查数比率とから, 平 均検查料を 78350 円とした。PET/CT 等により悪性腫瘍の病期診断が精密化することにより，手 術が 27\% 減少すると仮定した。これらの仮定に基づくと, PET/CT 等は 3164258753 円の医療費 削減効果があると試算された。熟練した診断医の慎重な PET/CT 等読影と, 臨床病歴・身体所見 ・検查結果・他の画像診断，とりわけ CT, とを総合的に判断して悪性腫瘍病期診断をいっそう正 確なものとし，この病期診断に基づいて合理的な治療方針を決定することが，医療の質の向上と医 療費節約に重要である。
\end{abstract}

Key Words : $\left[{ }^{18} \mathrm{~F}\right]$ FDG-PET, malignant neoplasm, medical economics, national health insurance system

\section{1.はじめに}

厚生労働省によって健康保険診療として承認 されている $\left.{ }^{18} \mathrm{~F}\right] \mathrm{FDG}-\mathrm{PET}$ 及び $\mathrm{PET} / \mathrm{CT}$ 複 合機検查（以下 $\mathrm{PET} / \mathrm{CT}$ 等）の適用疾患は, 墨性腫瘍に限ると, 肺癌, 乳癌, 食道癌, 大腸 癌, 㬸臓癌, 婦人科癌, 転移性肝癌, 頭頸部癌, 悪性リンパ腫, 悪性黒色腫, 原発不明癌, 及び 脳腫瘍（ただし， $\left.{ }^{[18} \mathrm{F}\right] \mathrm{FDG}-\mathrm{PET}$ 撮影のみ), である。我が国での臨床 PET の普及を目指し て, 諸外国での臨床 PET の使用状況との比較 から, 適用疾患リストの拡大と保険償還システ ムの確立が要望されている ${ }^{1)}$ 。最近行われた我 が国でのアンケート調査では, 現在の適用疾患
以外の悪性腫瘍にも有効性が示されている2)-5)。 日本核医学会はこのような要望と調查結果をふ まえて, 同学会健保委員会の検討をへて, PET/ CT 等によるすべての悪性腫瘍の病期診断と 再発・転移の診断とを, 平成 20 年の健康保険 診療報酬改訂で現在の適用に追加して保険償還 の対象とするよう, 厚生労働省に要望している。 このような適用疾患の拡大が行われた場合に, $\mathrm{PET} / \mathrm{CT}$ 等によって国民医療費が増加するこ とが当然予想される。一方で, PET/CT 等に よる病期診断能の向上は, 不要な医療行為を抑 制して医療費削減効果も予想できる。ここでは 日本核医学会健保委員会, 及び健保データベー ス小委員会がまとめた，両者の比較試算を示す。 


\section{2. 方 法}

$\mathrm{PET} / \mathrm{CT}$ 等の適用拡大による医療費の増加 は，適用拡大された疾患に対する $\mathrm{PET} / \mathrm{CT}$ 等 の合計件数に検查料を乗じて求めた。検査料は, 合同調査結果6)で判明した，20\% 減額された検 査の全検査に対する比率と, PET 検査数と $\mathrm{PET} / \mathrm{CT}$ 検査数の比率から加重平均を計算し て，78350円/件とした。

$\mathrm{PET} / \mathrm{CT}$ 等無しの病期診断では手術が選択 される患者が, $\mathrm{PET} / \mathrm{CT}$ 等によって病期診断 が変化する結果, 非手術とされることがある。 このような手術減少効果による医療費の減少を 試算した。手術の減少効果の推定は, 適用拡大 分の悪性腫瘍のうち, 胃癌, 肝癌, 胆囊癌, 前 立腺癌の 4 癌のみに行い, 他の癌は計算から除 外した。がん手術治療の医療費は診断群別分類 包括評価 (DPC) 医療費から計算した。

上記の試算に必要なデータについて, 以下の ように予測又は仮定した。

1） 2008 年の年間 PET 等検査数

日本核医学会及び関連団体による合同調査結 果 ${ }^{6}$ に基づいて 2006 年の年間検査件数を次の ように推定した。対象期間 1 か月の同調查で得 られた $\mathrm{PET} / \mathrm{CT}$ 等件数を 12 倍して年間検査 数を推定後, アンケート回収率 $(64.2 \%)$ と装 置の定期点検等のための休止を除く実働割合 （97\% と仮定）とで除し，更に同調査で判明し た総検査件数に含まれていた自費診療分 （10\%）を差し引いて，2006 年の年間検査件数 予測值とした。

2006 年の年間検査件数予測值と同調査で調 ベた 2006 年の PET 装置と PET/CT 装置合計 台数（312 台）とから，装置一台あたりの年間 検査件数を推定した。同調査に加え 2004 年の 調査 ${ }^{7)}$ と 2005 年の調査 ${ }^{8}$ での装置数から, 年間 装置増加数を計算した。装置設置時期の年度内 での相違を考慮して, 前年度末の装置台数に年 間増加数の $1 / 2$ を加えて, 2007 年と 2008 年の 装置台数を予測した。
装置一台あたりの年間検査件数を 2007 年以 降も2006 年と不変と仮定し，これに上記の予 測装置台数を乗じて，2008 年の年間検査件数 を予測した。

2） 2008 年の適用拡大分の年間 $\mathrm{PET} / \mathrm{CT}$ 等検 査数

2005 年調査 ${ }^{8}$ で施行された既適用疾患別 $\mathrm{PET} / \mathrm{CT}$ 等検査件数に, 既適用各疾患の罹患 率予測増加率を乗じて疾患別年間検査件数を予 測した。疾患別検査件数予測值を合計して, 既 適用疾患年間総検査数を予測した。この予測值 と, 左記 1) で得た年間検査件数予測值との差 を，適用拡大分の検査予測数とした。罹患率予 測増加率は地域がん登録全国推計によるがん罹 患データ ${ }^{9)}$ の全国推定年齢調整罹患率の1977 2001 年のデータから推定した。

3）適用拡大分悪性腫瘍の手術施行時の医療費 ひとつの癌に対して複数の手術手技 DPC コ ードが割り振られている場合は, 該当する全コ ードの手術手技料の平均を採用した（Table 1)。 医療機関別係数は 1.0 , 入院期間は DPC の II の期間として入院料を計算した。Table 1 の手 術技術料と麻酔技術料（6 100 点）にDPCの 入院期間の合計点数を加え, 一手術あたりの平 均点数を算出した。適用拡大分の悪性腫瘍の手 術適用率は国立がんセンターのがん登録データ から $53.4 \%$ とした。

4） $\mathrm{PET} / \mathrm{CT}$ 等による手術減少率

Hillner らの報告 ${ }^{11)}$ の $1 / 2$ である $27 \%$ と仮定 した。

\section{3. 結 果}

$3 \cdot 12008$ 年の年間 PET 等検査件数 2006 年 $^{6)}, 2005$ 年の調査 ${ }^{8)}$ と 2004 年の調查 ${ }^{7)}$ での年間装置増加数の平均から, 年間装置増加 数を 84 台と予測し, 2007 年と 2008 年の装置台 数を，それぞれ，353 台，397台と推測できた。 2006 年の装置一台あたりの検査数は 758 検査/ 年/台であり，これを用いて 2008 年の年間検査 件数予測值は，275 785 件となった。 
Table 1 Reimbursement for surgery of cancers based on Japanese DPC system

\begin{tabular}{llc}
\hline Cancer & Operation: DPC code & Reimbursement (x10 Yen) \\
\hline Gastric & Probe Laparotomy: K636 & 5,550 \\
& Gastrectomy for malignancy: K6552 & 42,600 \\
& Gastrectomy for malignancy: K6572 & 58,300 \\
Liver & Mean & 35,483 \\
& Radiofrequency ablation: K697-2 & 13,600 \\
& Hepatic partial resection: K6951 & 21,500 \\
& Hepatic extended lobar resection: K6954 & 64,700 \\
& Hepatic extended lobar resection with vascular & \\
Gallbladder/ & Malignancy confined to gall bladder: K6751 & 71,700 \\
Bile duct & Pancreatoduodenectomy: K6753 & 42,875 \\
& Mean & 28,500 \\
Prostate & Prostate surgery for malignancy: K843 & 46,300 \\
& Mean & 31,600 \\
& & 31,600 \\
\hline
\end{tabular}

$3 \cdot 22008$ 年の適用拡大分の年間 PET 検査 数

年間 275785 件のうち，既適用分の検査が疾 患増加率から年間 249073 件と予測されたので, 適用拡大分の年間 PET 検査件数予測值は, 26712 件となった。

\section{$3 \cdot 32008$ 年の医療費削減効果}

年間 FDG 検査は, 26712 件増加し, 検査料 78350 円/件としたので, FDG 検査料は 2092885200 円増加した $(26712 \times 78350=$ 2092885200 円)。

適用拡大分悪性腫瘍の手術療法の医療費は Table 2 のように計算された。PET 無しでは $53.4 \%$ に手術が施行されるが，PET の使用に より手術数が $27 \%$ 減少するとの前述の予測か ら，四種類の癌の平均医療費である 1350018 円を用いて，医療費削減は5 257143953 円 $(26712 \times 1350018 \times 0.534 \times 0.27=$ 5257143953 円）と試算できた。正味の医療費 削減額は両者の差である, 3164258753 円とな った（5257143953-2092885 200）。

\section{4. 考察}

$\mathrm{PET} / \mathrm{CT}$ 等を悪性腫瘍の病期診断に使用す

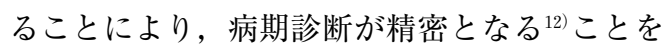
通じて, 手術の減少 ${ }^{13)}$ が期待できる。手術の減 少による医療費削減効果が, 検查施行による医 療費の増加を上回る結果，医療費の削減につな がるとの試算結果であった。すでに適用のある 悪性腫瘍の診療においても, PET/CT 等を病 期診断に使用した場合に検査料の増加を手術削 減効果が上回るとの試算結果が出ている（日本 核医学会提出の平成 20 年診療報酬改定に向け た医療技術評価希望書，未発表データ)。すな わち, PET/CT 等は, 治療方針を手術から非 手術へと変更させることにより医療費削減効果 を現しうることがわかった。

本論文の試算，及び，前記の医療技術評価希 望書の試算では, 手術有りと無し時の医療費の 差額（すなわち, Table 2 の右欄值と左欄値の 差額）と, $\mathrm{PET} / \mathrm{CT}$ 等の検査増加による医療 費増加との差をもって医療費削減効果とはして いない。これは一見 PET/CT 等に有利な試算 であるが，著者はそのようには考えない。不要 な手術をうけた患者は早晚, 本来最初から受け 
Table 2 Estimated reimbursement/patient for malignant neoplasm included in the expanded indication for $\left[{ }^{18} \mathrm{~F}\right] \mathrm{FDG}-\mathrm{PET}$ or $\mathrm{PET} / \mathrm{CT}$

\begin{tabular}{llc}
\hline Cancer & \multicolumn{2}{c}{ Reimbursement*, (Yen) } \\
\cline { 2 - 3 } & without surgery & with surgery \\
\hline Stomach & 575,587 & $1,295,129$ \\
Liver & 576,447 & $1,276,875$ \\
Gall bladder & 609,417 & $1,842,313$ \\
Prostate & 272,815 & 869,935 \\
Mean of the Above & 542,245 & $1,350,018$ \\
\hline
\end{tabular}

* Reimbursement was calculated based on all applicable DPC codes related with each of the cancers listed on the left column.

るべきであった非手術治療をうけることになる。 この結果, 手術治療の医療費に加え, 非手術治 療の医療費も追って必要になる。たとえば PET 無しで臨床病期 I 期とされ手術をうけたが短期 間内に遠隔転移を生じた場合を考える。PET 無しでは手術治療の医療費がかかり, 転移が臨 床的に明らかになった時点で非手術治療の医療 費が追加される。術前にPETを行った結果思 いがけない転移巣が早期に見つかったとすれば, 手術は行われず非手術治療の医療費のみが必要 となる。したがって, 医療費削減効果は手術治 療の医療費全額となる。

$\mathrm{PET} / \mathrm{CT}$ 等検査料の計算にあたって, 加重 平均を用いたが, 将来 $\mathrm{PET} / \mathrm{CT}$ が増加し相対 的にPET が減少すると平均検査料は試算より 高くなると予想される。しかし，試算結果では 検査料による医療費増加は医療費削減効果の $40 \%$ 程度で, 検査料が 2.5 倍未満程度まで上 昇しても正味の医療費削減効果はまだ保たれ, 大きな影響を試算に与えないと思われる。

適用拡大分の悪性腫瘍のうち, 胃癌, 肝癌, 胆囊癌, 前立腺癌の 4 癌のみを計算対象とした のは，これ以外の悪性腫瘍は手術削減効果に関 するデータがなく, 更に比較的少ない癌である ので，影響が小さいと考えたからである。この ため, 適用拡大分にしめる, 4 癌以外の癌の割 合が増加した場合の予測はできていない。肝癌
については, 原発及び転移性肝癌において, 肝 臓外の病巣を検出するのに有用との報告 ${ }^{14)}$ があ る。前立腺癌についても, 組織学的悪性度が高 い，あるいはPSA が急速に上昇する場合には 病期診断に有用とされている ${ }^{15)}$ 。肝癌及び前立 腺癌は一般に FDG-PET/CT 等の有用性は低 いとされるため, 上記文献に示された一部の病 態での使用に限るのが望ましく, 更なるデータ の集積と解析が必要である。すべての悪性腫瘍 へと適用を拡大することにより，神経内分泌腫 瘍, 骨軟部腫瘍, 胸膜腫瘍, 生殖 - 泌尿器腫瘍 も含まれる。これらの腫瘍については, 癌登録 をもとにデータを収集して有効性を示すデータ が得られるか常時検証するシステムの構築が医 療の質を向上させつつ医療費削減を果たすため に必要と思われる。

がん手術治療の医療費は DPC 医療費から計 算したが，出来高払いによる手術治療の医療費 の計算は, 手術自体の医療費は計算できても, 手術に伴って必要な入院治療費が, 医療機関や 患者により大きく変動して, 計算困難であると 考えたためである。

本論文の計算には更にいくつかの不完全な点 がある。手術費用の算定には各診断区分別 (DPC コード別) の症例数が公表されていない ため, 単純に平均をとらざるをえなかったこと が一点である。原発巣ごとの PET/CT 等によ 
る手術減少率のデー夕が存在しないため，大ま かな推定によらざるを得なかった点が第二であ る。この二点は医療費削減について非常に大き な影響をあたえるので，本試算には限界がある ことに留意しなければならない。この試算では 手術削減率は $27 \%$ とした。Hillner らの 248 例 の報告 ${ }^{11)}$ では PET 施行前に 22 例が手術とされ たが, PET 施行後には 10 例になったとの成績 で, 手術が 55\% 減少していた。一方, Anderson らは胆管癌では $30 \%$ で思いがけない転移が見 つかり治療方針が $30 \%$ で大きく変更されたと 報告している ${ }^{16)}$ 。この二論文から Hillner ら ${ }^{11)}$ の $1 / 2$ である $27 \%$ と推定した。

$\mathrm{PET}$ 又は $\mathrm{PET} / \mathrm{CT}$ 診断も決して完全ではな く, 偽陽性・偽陰性診断が生じる。これが医療 費削減効果を減少させると予想される。この懸 念は本論文の試算では一部回避されている。本 論文に採用した手術削減効果は, PET/CT 等 による偽陽性診断で増える手術と真陽性診断に より減少する手術とを計算にいれた正味の削減 効果だからである。また PET/CT は現時点で は偽陽性・偽陰性診断のもっとも少ない最良の 病期診断能を有する検査であり ${ }^{12)}$, 少なくとも 理論上は, 他の検査が PET/CT を超えること はなく，医療費削減効果は保たれると推論でき る。

最後に，本試算は現在の医療費計算法に基づ いており，医療制度の変更によっても変動する 点にも注意が必要である。また，この試算が有 効であるためには, 医療経済的観点のみならず 医療の質の確保にも留意されねばならない。 $\mathrm{PET} / \mathrm{CT}$ 等による診断が文献での診断能に匹 敵するよう, 注意深く検査が施行され, 読影さ れ, その結果が臨床各科に受け入れられ, 診療 行動に適切に反映されるように努力することが 求められる。医療の質を確保するため, 日本核 医学会は日本医学放射線学会に協力して, PET/ CT 検査施行のガイドライン ${ }^{17)}$ を公表している。 このガイドラインの趣旨を尊重した医療を行う ことが求められる。
医療本来の観点からは，PET/CT 等が医療 費の削減に結びつくか否かではなく, 治療方針 がどの程度変化し, その結果患者の QOL 向上 に役立つか否かが最重要である。

\section{5. ま と め}

FDG-PET 等は悪性腫瘍の病期診断精密化を とおして，検査費用に上回る医療費削減効果を 発揮できる可能性がある。不要な手術の減少に より，患者 QOL 向上にも寄与できる。

\section{謝 辞}

本論文の内容は, 日本核医学会健保委員会及 び日本核医学会健保データベース小委員会の活 動によるものである。

\section{文献}

1）田代 学, 窪田和雄, 伊藤正敏, 藤本敏彦, 山 口一郎, 佐々木英忠, Ernst Moser, 諸外国にお ける臨床 PET の現況, 核医学, 38, 255-256 (2001)

2）東 達也，伊藤健吾，鳥塚莞爾，肝細胞癌，胆 管癌, 胆囊癌の診断における $\left[{ }^{18} \mathrm{~F}\right] \mathrm{FDG}-\mathrm{PET}$ の 臨床的有用性一多施設アンケート調查による検 討一, RADIOISOTOPES , 57(1), 1-11(2008)

3）加藤克彦, 細野 眞, 伊藤健吾, 岡田真広, 米矢 吉宏, 任 誠雲, 土屋典生, 鳥塚莞爾, 骨軟部 腫瘍の診断における $\left.{ }^{18} \mathrm{~F}\right] \mathrm{FDG}-\mathrm{PET}$ 検查の臨床 的有用性一多施設アンケート調查による検討一, RADIOISOTOPES, 57 (1), 13-23(2008)

4）鳥塚達郎, 伊藤健吾, 鳥塚莞爾, 胃癌, 十二指 腸乳頭部癌, GIST (消化管間葉系腫瘍) の診断 における $\left.{ }^{18} \mathrm{~F}\right] \mathrm{FDG}-\mathrm{PET}$ の臨床的有用性一多施 設アンケート調查による検討一, RADIOISOTOPES , 57 (1), 25-31 (2008)

5）鳥塚莞爾，伊藤健吾，健康保険適用外の 18 種類 の腫場に扔ける $\left[{ }^{18} \mathrm{~F}\right] \mathrm{FDG}-\mathrm{PET}$ の臨床的有用性 一多施設アンケート調查による検討一, RADIOISOTOPES, $\mathbf{5 7}$ (1), 33-43(2008)

6） PET 検查件数に関するアンケート調查報告 第 4 報，Isotope News，645(1), 32-35(2008)

7） PET 検査件数に関するアンケート調査報告 第 2 報，Isotope News，610(2),30-31(2005)

8） PET 検查件数に関するアンケート調查報告 第 
3 報，Isotope News，630(10)，27-29(2006)

9）国立がんセンターがん対策情報センター, 地域 がん登録全国推計によるがん罹患データ（1975 年 〜 2001 年), cancer_incidence(1975-2001).xls, http : //ganjoho.ncc.go.jp/professional/statistics/ statistics.html

10）国立がんセンター中央病院院内がん登録，がん の治療法（国立がんセンター中央病院, 初発症 例：昭和 50 年度.平成 16 年の比較), http : // ganjoho.ncc.go.jp/public/statistics/backnumber/ odjrh3000000h332-att/fig12.pdf

11) Hillner, B. E., Tunuguntla, R. and Fratkin, M., Clinical decisions associated with positron emission tomography in a prospective cohort of patients with suspected or known cancer at one United States center, J. Clin. Oncol., 22, 41474156 (2004)

12) Antoch, G., Saoudi, N., Kuehl, H., Dahmen, G., Mueller, S. P. et al., Accuracy of whole-body dual modality Fluorine-18-2Fluoro-2-2Deoxy-D-glucose positron emission tomography and computed tomography (FDG-PET/CT) for tumor staging in solid tumors : Comparison with CT and PET, $J$. Clin. Oncol ., 22, 4357-4368 (2004)

13) van Tinteren, H., Hoekstra, O. S., Smit, E. F., van den Bergh, J. H., Schreus, A. J. et al., Effectiveness of positron emission tomography in the preoperative assessment of patients with suspected non-small-cell lung cancer: the PLUS multicentre randomized trail, Lancet, 359, 1388-1392 (2002)

14) Bolm, B., Voth, M., Geoghegan, J., Hellfritzsch, H., Petrovich, A., Scheele, J. and Gottschild, D., Impact of positron emission tomography on strategy in liver resection for primary and secondary liver tumors, J. Cancer Res. Clin. Oncol., 130, 266272(2004)

15) Shvarts, O., Han, K., Seltzer, M., Pantruck, A. J. and Belldegrun, A. S., Positron emission tomography in urologic oncology, Cancer Control, $\mathbf{9}$, 335-342(2002)

16) Anderson, C. D., Rice, M. H., Prinson, C. W., Chapman, W. C., Chari, R. S., Delbeke, D., Fluorodeoxyglucose PET imaging in the evaluation of gallbladder carcinoma and cholangiocarcinoma, J. Gastrointest Surg ., 8, 90-97 (2004)

17）社団法人日本医学放射線学会, FDG-PET/CT 検査施行のガイドライン, http : //www.radiology. jp/modules/news/article.php?storyid $=120$ 


\title{
Abstract
}

\section{Estimation of Economic Impact by Proposed Expansion of $\left[{ }^{18}\right.$ F] FDG-PET Indication on Japanese National Health Insurance System : FDG-PET for All Malignant Neoplasms May Save Reimbursement}

\author{
Norinari Honda, Kengo ITo* and Kanji Torizuka** \\ for the members of the committee of health insurance system and the subcommittee \\ of health insurance database of the Japanese Society of Nuclear Medicine \\ Department of Radiology, Saitama Medical Center, Saitama Medical University \\ 1981 Tsujido, Kawagoe-shi, Saitama Pref. 350-8550, Japan \\ * National Center for Geriatrics and Gerontology \\ 36-3 Gengo, Morioka-cho, Obu-shi, Aichi Pref. 474-8522, Japan \\ ** Director, Chairman, Health Research Foundation \\ Pasteur Bldg. 5F, 103-5, Tanaka-monzen-cho, Sakyo-ku, Kyoto-shi, Kyoto 606-8225, Japan
}

\begin{abstract}
Effect of expansion of $\left[{ }^{18} \mathrm{~F}\right] \mathrm{FDG}-\mathrm{PET}$ or $\mathrm{PET} / \mathrm{CT}$ indication for all malignancy on reimbursement of the Japanese national health insurance system was calculated since the health insurance system is now facing with financial difficulties. The number of the PET examinations was estimated to be $275785 /$ year at 2008 from results of the three consecutive surveys of questionnaire from 2004 to 2006. Reimbursement per PET or $\mathrm{PET} / \mathrm{CT}$ examination was calculated as ¥78 350 based on the frequency of 20\%-discounted examination and $\mathrm{PET}$ to $\mathrm{PET} / \mathrm{CT}$ study ratio. Stage shift brought by FDG-PET or PET/CT was assumed to decrease futile operations by $27 \%$. Based on these figures, it was estimated that an annual reimbursement in 2008 would be reduced by $¥ 3164258$ 753. Careful inspection and proper interpretation based on appropriate integration of clinical history, physical examination, laboratory data, and results of other imaging studies, particularly CT, is the key to attain improved patient care with reduced cost.
\end{abstract}

(Received September 10, 2007) 